\title{
Synthesis and Properties of Polyguanamines from Bisguanamines and $\alpha, \omega$-Dibromoalkanes by Alkylation Reaction
}

\author{
Yasuo Yuki, ${ }^{*}$ Hideo Kunisada, Kazuhiro Iida, \\ and Shuji Kondo \\ Department of Materials Science and Engineering, \\ Nagoya Institute of Technology, \\ Gokiso-cho, Showa-ku, Nagoya 466, Japan
}

(Received July 24, 1995)

\begin{abstract}
The novel polyguanamines were synthesized by condensation reaction of bisguanamines with $\alpha, \omega$-dibromoalkanes in the presence of sodium hydride. The polyguanamines having inherent viscosities of $0.1-0.2 \mathrm{dl} \mathrm{g}^{-1}$, were obtained quantitatively. They began to lose weight around $400-480^{\circ} \mathrm{C}$ in air. The abilities as polymeric phase transfer catalyst of resulting polyguanamines were also investigated. They could use as effective phase transfer catalysts for the reaction of 1-bromooctane with potassium thiocyanates in toluene-water systems.
\end{abstract}

KEY WORDS Guanamine/Bisguanamine/Polyguanamine/ $\alpha, \omega$-Dibromoalkane / 1,3,5-Triazine / Polycondensation / Alkylation / Phase Transfer Catalyst /

Polyguanamines, as a thermally stable polymer, have been prepared by the reaction of dibiguanide derivatives with dicarboxylic acid dichlorides or phenyl esters, ${ }^{1-3}$ or the reaction of diphenoxy-1,3,5-triazines with benzoguanamine as a diamine. ${ }^{4}$ These polyguanamines are soluble in sulfuric acid but insoluble in common organic solvents.

Recently, we reported the alkylation reaction of 2-amino-4-anilino-6-isopropenyl-1,3,5-triazine $^{5,6}$ or 2,4-dianilino-6-isopropenyl-1,3,5triazine ${ }^{7}$ with alkyl bromides in the presence of sodium hydride with the purpose of monomer synthesis for new comb-like polymers. The alkylation reaction proceeded quantitatively and selectively on the imino position in anilino group through the anilide anion, which could be followed by NMR measurements. ${ }^{5}$

This paper describes the new synthesis of polyguanamines by the alkylation reaction of bisguanamines with $\alpha, \omega$-dibromoalkanes, as an application of above alkylation reaction (Scheme 1). The thermal properties and the abilities as a polymeric phase transfer catalyst

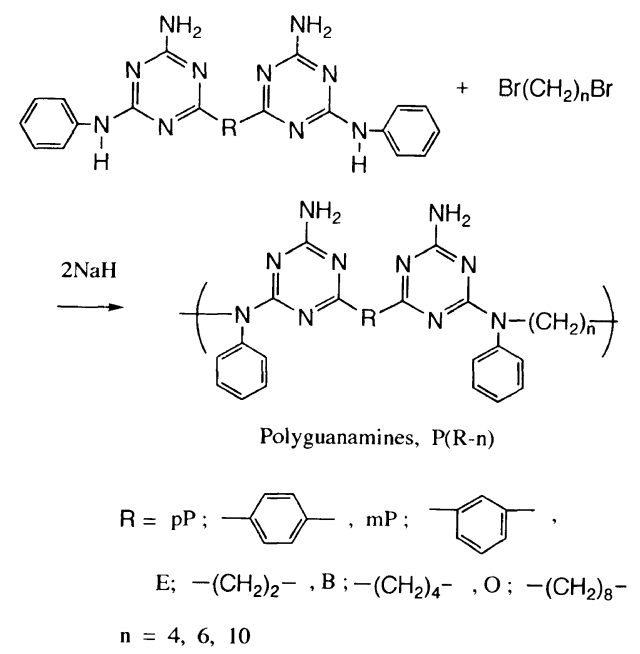

Scheme 1.

\footnotetext{
* To whom all correspondence should be addressed.
} 
of the resulting polyguanamines were also investigated.

\section{EXPERIMENTAL}

\section{Materials}

Phenyldicyanodiamide (PhDD) was prepared according to a literature procedure. ${ }^{8} \mathrm{mp}$ $196^{\circ} \mathrm{C}$ (lit. ${ }^{8} 196-197^{\circ} \mathrm{C}$ ).

\section{Bisguanamines as Monomers}

1,4-Bis(4-amino-6-anilino-1,3,5-triazin-2yl)benzene (1a) was prepared by reaction of $12.9 \mathrm{~g}(0.10 \mathrm{~mol})$ of terephthalonitrile with $35.6 \mathrm{~g}(0.23 \mathrm{~mol})$ of $\mathrm{PhDD}$ in $120 \mathrm{ml}$ of dimethylformamide (DMF) in the presence of $6.22 \mathrm{~g}$ of potassium hydroxide at reflux for $5 \mathrm{~h}$. The solution was cooled to give white product, which was filtered off, washed with methanol and dried. The filtrate was poured into water to give a product. The product was totally yielded $33.7 \mathrm{~g}(74.7 \%)$. 1a was recrystallized from dimethylformamide. $\mathrm{mp} 349^{\circ} \mathrm{C}$ (lit. $^{3}$ $357^{\circ} \mathrm{C}$ ). Anal. Calcd for $\mathrm{C}_{24} \mathrm{H}_{20} \mathrm{~N}_{10}$ : C, $64.24 \%$; H, 4.49\%; N, 31.23\%. Found: C, $64.10 \% ; \mathrm{H}, 4.52 \% ; \mathrm{N}, 31.38 \%$.

Other monomers $(\mathbf{1 b}-\mathbf{1 e})$ were prepared by a similar method using the corresponding dinitriles (Scheme 2).

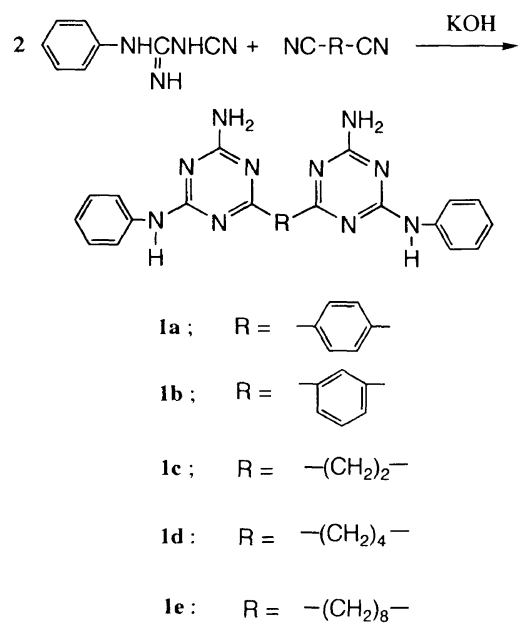

Scheme 2.
1,3-Bis(4-amino-6-anilino-1,3,5-triazin-2yl)benzene (1b). Yield was $74.7 \%$. mp $322^{\circ} \mathrm{C}$ (lit. $327^{\circ} \mathrm{C}$ ). Anal. Calcd for $\mathrm{C}_{24} \mathrm{H}_{20} \mathrm{~N}_{10}$ : C, $64.24 \%$; H, 4.49\%; N, 31.23\%. Found: C, $64.43 \% ; \mathrm{H}, 4.31 \% ; \mathrm{N}, 31.24 \%$.

1,2-Bis(4-amino-6-anilino-1,3,5-triazin-2yl)ethane (1c). Yield was $64.6 \% \cdot \mathrm{mp} 263^{\circ} \mathrm{C}$ (lit. ${ }^{3} 261^{\circ} \mathrm{C}$ ). Anal. Calcd for $\mathrm{C}_{20} \mathrm{H}_{20} \mathrm{~N}_{10}$ : C, $59.99 \%$; H, $5.03 \%$; N, 34.98\%. Found: C, $60.11 \% ; \mathrm{H}, 4.92 \% ; \mathrm{N}, 34.97 \%$.

1,4-Bis-(4-amino-6-anilino-1,3,5-triazin-2yl)butane (1d). Yield was $41.3 \%$. mp $226^{\circ} \mathrm{C}$ (lit. ${ }^{3} 243^{\circ} \mathrm{C}$ ). Anal. Calcd for $\mathrm{C}_{22} \mathrm{H}_{24} \mathrm{~N}_{10}$ : C, $61.67 \%$; H, 5.65\%; N, 32.69\%. Found: C, $61.67 \% ; \mathrm{H}, 8.15 \%$; N, 32.67\%.

1,8-Bis(4-amino-6-anilino-1,3,5-triazin-2yl)octane (1e). Yield was $66.6 \% \mathrm{mp} 220^{\circ} \mathrm{C}$ (lit. ${ }^{3} 230^{\circ} \mathrm{C}$ ). Anal. Calcd for $\mathrm{C}_{26} \mathrm{H}_{32} \mathrm{~N}_{10}$ : C, $64.44 \%$; H, 6.66\%; N, 28.90\%. Found: C, $64.32 \% ; \mathrm{H}, 6.68 \%$; N, $28.84 \%$.

\section{Model Compounds}

1,4-Bis[4-amino-6-( $N$-hexylanilino)-1,3,5triazin-2-yl]benzene (2a) was prepared by the alkylation reaction of $1 \mathbf{a}(2.24 \mathrm{~g}, 5 \mathrm{mmol})$ with 1-bromohexane $(1.65 \mathrm{~g}, 10 \mathrm{mmol})$ in the presence of sodium hydride $(60 \%$ suspension in paraffin, $0.40 \mathrm{~g}, 10 \mathrm{mmol})$ in dimethyl sulfoxide (DMSO) $(15 \mathrm{ml})$ at $60^{\circ} \mathrm{C}$ for $5 \mathrm{~h}$ with stirring. The reaction mixture was poured into water to give $3.10 \mathrm{~g}(100 \%)$ of $\mathbf{2 a}$, which was recrystallized from tetrahydrofuran (THF). $\mathrm{mp}$ $264^{\circ} \mathrm{C}$.

Other model compounds, 1,3-bis[4-amino6-( $N$-hexylanilino)-1,3,5-triazin-2-yl]benzene (2b), 1,2-bis[4-amino-6-( $N$-hexylanilino)-1,3,5triazin-2-yl]ethane (2c), and 1,4-bis[4-amino6-( $N$-hexylanilino)-1,3,5-triazin-2-yl]butane (2d) were prepared by a similar method (Table I).

\section{Polycondensation}

$1 \mathrm{a}(2.243 \mathrm{~g}, 5.00 \mathrm{mmol})$ was added to DMSO $(15 \mathrm{ml})$ in the presence of sodium hydride $(0.40 \mathrm{~g}, 10 \mathrm{mmol})$ with stirring, and DMSO solution $(6 \mathrm{ml})$ of 1,10 -dibromodecane $(1.501 \mathrm{~g}$, 
$5.00 \mathrm{mmol}$ ) was added dropwise and stirred at $50^{\circ} \mathrm{C}$ for $24 \mathrm{~h}$. The reaction mixture was then poured into excess methanol. The isolated polyguanamine $\mathrm{P}(\mathrm{pP}-10)$ was washed with methanol, reprecipitated from THF into hexane, and dried under vacuum to give a yield of $2.87 \mathrm{~g}(97.9 \%)$.

Other polyguanamines were prepared by analogous procedure (Table III).

\section{Catalytic Activities for Substitution Reaction}

Catalytic activities of polyguanamines were tested in the two-phase reactions of 1-bromooctane in toluene with potassium thiocyanate in water. In a typical run, a toluene solution $(1 \mathrm{ml})$ of 1 -bromooctane $(0.319 \mathrm{~g}, 1.654$ $\mathrm{mmol}$ ), a water solution of potassium thiocyanate $(3.88 \mathrm{~g}, 40 \mathrm{mmol})$, and polyguanamine $\mathrm{P}(\mathrm{pP}-10)$ (0.1752 g, $0.299 \mathrm{mmol})$ were charged in a test tube with a screw-cock. An internal standard (cyclohexylbenzene) was added to the reaction mixture and the tube was heated at $100^{\circ} \mathrm{C}$ for $30 \mathrm{~h}$ with stirring. Then the reaction mixture was poured in petroleum ether to precipitate a solid, and the filtrate was analyzed by gas chromatography. The yield of octyl thiocyanate was $74 \%$.

\section{Measurement}

Elementary analyses were performed on a Yanaco CHN corder MT-3 analyzer. ${ }^{1} \mathrm{H}$ NMR spectra were recorded on a Hitachi R-600 $(60 \mathrm{MHz})$ or a Varian XL-200 $(200 \mathrm{MHz})$ spectrometer. Molecular weight of polymers was determined by gel permeation chromatography (GPC) on a TOSOH HLC-803D with $\mathrm{G} 2000 \mathrm{H}, \mathrm{G} 3000 \mathrm{H}$, and GMH TSK gel-columns and a differential refractometric detector in THF. The columns were calibrated with a set of monodisperse polystyrene standards. The glass transition temperature $\left(T_{\mathrm{g}}\right)$ of polymers was determined by differential scanning calorimetry (DSC) on a Rigaku-Denki DSC8230 at a heating rate of $20^{\circ} \mathrm{Cmin}^{-1}$. Decomposition temperature $\left(T_{\mathrm{d}}\right)$ of polymers was measured by the thermogravimetry on a
Rigaku TG-DTA $8112 \mathrm{BH}$ thermal analyzer system at a heating rate of $10^{\circ} \mathrm{C} \mathrm{min}^{-1}$. Gas chromatography (Ohkura 802T) was used for the yield determination of $n$-octyl thiocyanate.

\section{RESULTS AND DISCUSSION}

\section{Monomers Synthesis}

Five bisguanamines $(\mathbf{1 a - 1 e )}$ as monomers, were prepared by the reaction of the corresponding dinitriles with double molar quantity of PhDD under alkaline condition (Scheme 2). The elemental analyses of these compounds were in good agreement with the calculated values for the proposed structures.

\section{Model Compounds}

The model reactions of bisguanamines with double molar quantity of 1-bromohexane in the presence of sodium hydride were examined (Scheme 3). The results are shown in Table I. The reactions proceeded under mild conditions and gave dialkylated model compounds $(\mathbf{2 a}-\mathbf{2 d})$ in an excellent yield. The chemical structures of all model compounds were confirmed by means of elemental analysis, IR, and NMR spectroscopic methods. The NMR spectra of model compounds (Table II) display the signal of $\mathrm{N}-\mathrm{CH}_{2}$ group at $4.0 \mathrm{ppm}$. Since the four protons of two amino groups remain at $6.9 \mathrm{ppm}$ for $\mathbf{2 a}$ and $\mathbf{2 b}$, and $6.7 \mathrm{ppm}$ for $\mathbf{2 c}$

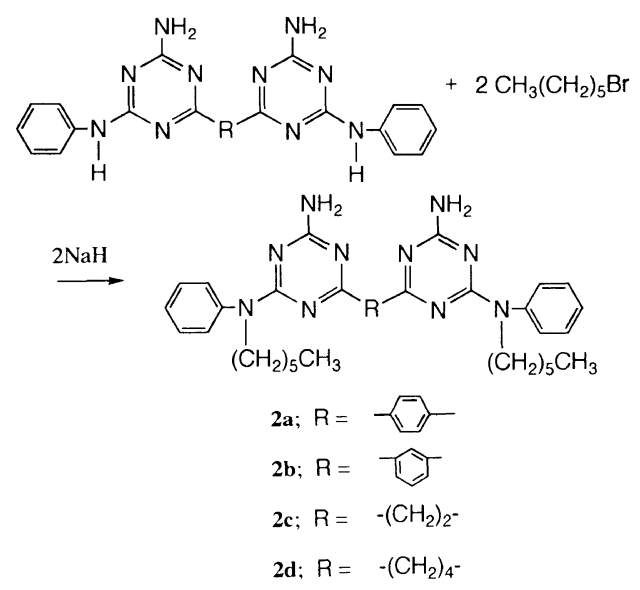

Scheme 3. 
Y. YUKI, H. KunisADA, K. IIDA, and S. Kondo

Table I. Synthesis of model compounds

\begin{tabular}{|c|c|c|c|c|c|c|c|}
\hline \multirow{2}{*}{$\begin{array}{c}\text { Model } \\
\text { compound }\end{array}$} & \multirow{2}{*}{$\frac{\text { Temp } / \text { Time }^{\mathrm{a}}}{{ }^{\circ} \mathrm{C} / \mathrm{h}}$} & \multirow{2}{*}{$\frac{\text { Yield }}{\%}$} & \multirow{2}{*}{$\frac{\mathrm{mp}}{{ }^{\circ} \mathrm{C}}$} & \multicolumn{4}{|c|}{ Elementary analysis (calcd) } \\
\hline & & & & $\mathrm{C} \%$ & $\mathrm{H} \%$ & $\mathrm{~N} \%$ & \\
\hline \multirow[t]{2}{*}{$2 \mathbf{a}$} & $60 / 5$ & 100 & 264 & 70.07 & 7.23 & 22.70 & \\
\hline & & & & $(70.10$ & 7.19 & 22.71 & $\left.\mathrm{C}_{36} \mathrm{H}_{44} \mathrm{~N}_{10}\right)$ \\
\hline \multirow[t]{2}{*}{$\mathbf{2 b}$} & r.t. $/ 28$ & 99 & 222 & 70.14 & 7.15 & 22.71 & \\
\hline & & & & $(70.10$ & 7.19 & 22.71 & $\left.\mathrm{C}_{36} \mathrm{H}_{44} \mathrm{~N}_{10}\right)$ \\
\hline \multirow[t]{2}{*}{$2 c$} & r.t./22 & 99 & 212 & 67.71 & 7.90 & 24.31 & \\
\hline & & & & $(67.58$ & 7.80 & 24.63; & $\left.\mathrm{C}_{32} \mathrm{H}_{44} \mathrm{~N}_{10}\right)$ \\
\hline \multirow[t]{2}{*}{ 2d } & r.t. $/ 22$ & 98 & 117 & 68.34 & 8.15 & 23.52 & \\
\hline & & & & $(68.43$ & 8.11 & 23.47 & $\left.\mathrm{C}_{34} \mathrm{H}_{48} \mathrm{~N}_{10}\right)$ \\
\hline
\end{tabular}

${ }^{a}$ Bisguanamine used $5 \mathrm{mmol}$ and 1-bromohexane used $10 \mathrm{mmol}$ in DMSO $13-18 \mathrm{ml}$.

Table II. ${ }^{1} \mathrm{H}$ NMR data of model compounds in DMSO- $d_{6}(\delta \mathrm{ppm})$<smiles>CCCN(c1ccccc1)c1nc(N)nc(Pc2nc(N)nc(N(CCC)c3ccccc3)n2)n1</smiles>

\begin{tabular}{ccccccc}
\hline $\begin{array}{c}\text { Model } \\
\text { compound }\end{array}$ & $\begin{array}{c}\mathrm{NH}_{2} \\
(4 \mathrm{H}, \mathrm{brs})\end{array}$ & $\begin{array}{c}\mathrm{Ph} \\
(10 \mathrm{H}, \mathrm{s})\end{array}$ & $\begin{array}{c}\mathrm{CH}_{2}{ }^{\mathrm{a}} \\
(4 \mathrm{H}, \mathrm{t})\end{array}$ & $\begin{array}{c}\left(\mathrm{CH}_{2}\right)_{4}{ }^{\mathrm{b}} \\
(16 \mathrm{H}, \mathrm{br})\end{array}$ & $\begin{array}{c}\mathrm{CH}_{3}{ }^{\mathrm{c}} \\
(6 \mathrm{H}, \mathrm{t})\end{array}$ & \multicolumn{2}{l}{$\mathrm{R}$} \\
\hline $\mathbf{2 a}$ & 6.93 & 7.40 & 4.06 & 1.29 & 0.87 & $8.37(4 \mathrm{H}, \mathrm{s})$ \\
$\mathbf{2 b}$ & 6.90 & 7.42 & 4.06 & 1.28 & 0.84 & $9.21(1 \mathrm{H}, \mathrm{s}), 8.38(2 \mathrm{H}, \mathrm{d}), 7.55(1 \mathrm{H}, \mathrm{t})$ \\
$\mathbf{2 c}$ & 6.66 & 7.24 & 3.91 & 1.26 & 0.82 & $2.74(4 \mathrm{H}, \mathrm{s})$ \\
$\mathbf{2 d}$ & 6.68 & 7.25 & 3.93 & 1.21 & 0.81 & $2.39(4 \mathrm{H}, \mathrm{t}), 1.65(4 \mathrm{H}, \mathrm{t})$ \\
\hline
\end{tabular}

and $\mathbf{2 e}$, respectively, any side reaction does not occurred on the pendant amino groups. The signal of phenyl protons became singlet absorption by alkylation on imino group in anilino group as previously reported. ${ }^{1}$

\section{Preparation of Polyguanamines}

On the basis of the results on the model reaction, polyguanamines were prepared by the polycondensation of bisguanamines with 1,4dibromobutane, 1,6-dibromohexane, and 1,10dibromodecane. Scheme 1 shows the structures of the polyguanamines, and the results of synthesis of polyguanamines are listed in Table
III. Polyguanamines P(R-n) were successfully obtained in almost quantitative yields with inherent viscosities of $0.1-0.2 \mathrm{dlg}^{-1}$. The precipitation of the polymers occurred during the course of most of the polycondensation because of relatively low solubilities of polymers. This may be the reason of the polymers with relatively low viscosity values.

The structures of these polymers were identified by elementary analysis, IR, and NMR spectroscopy. The results of the analysis agreed well with the calculated values. IR spectra of polyguanamines showed characteristic $\mathrm{CH}_{2}$ stretching band at 2950 and $2850 \mathrm{~cm}^{-1}$, 
Polyguanamine from Bisguanamine and $\alpha, \omega$-Dibromoalkane

Table III. Syntheses of polyguanamines from bisguanamines and $\alpha, \omega$-dibromoalkanes

\begin{tabular}{|c|c|c|c|c|c|c|c|c|}
\hline \multirow{2}{*}{ Polymer } & \multirow{2}{*}{$\frac{\text { Solvent }^{\mathrm{a}}}{\mathrm{m} l}$} & \multirow{2}{*}{$\begin{array}{c}\text { Yield } \\
\frac{\%}{}\end{array}$} & \multirow{2}{*}{$\frac{\eta_{\mathrm{sp}} / c^{\mathrm{b}}}{\mathrm{dlg} \mathrm{g}^{-1}}$} & \multicolumn{2}{|c|}{$\mathrm{GPC}^{\mathrm{c}}$} & \multicolumn{3}{|c|}{ Elementary analysis (calcd) } \\
\hline & & & & $M_{n} / 10^{3}$ & $M_{w} / M_{n}$ & $\mathrm{C} \%$ & $\mathrm{H} \%$ & N\% \\
\hline \multirow[t]{2}{*}{$\mathrm{P}(\mathrm{pP}-4)$} & $\operatorname{DMSO}(15) \&$ & 100 & 0.19 & - & - & 67.45 & 5.33 & 27.22 \\
\hline & $\operatorname{DMA}(8)$ & & & & & $(66.92$ & 5.21 & $\left.27.87 ; \mathrm{C}_{28} \mathrm{H}_{26} \mathrm{H}_{10}\right)$ \\
\hline \multirow[t]{2}{*}{$\mathrm{P}(\mathrm{pP}-6)$} & $\operatorname{DMSO}(40)$ & 103 & 0.19 & - & - & 68.27 & 5.84 & 25.89 \\
\hline & & & & & & $(67.91$ & 5.70 & $\left.26.40 ; \mathrm{C}_{30} \mathrm{H}_{30} \mathrm{~N}_{10}\right)$ \\
\hline \multirow[t]{2}{*}{$\mathrm{P}(\mathrm{pP}-10)$} & $\operatorname{DMSO}(21)$ & 98 & 0.17 & 一 & - & 69.35 & 6.68 & 23.61 \\
\hline & & & & & & $(69.60$ & 6.53 & $\left.23.87 ; \mathrm{C}_{34} \mathrm{H}_{38} \mathrm{~N}_{10}\right)$ \\
\hline \multirow[t]{2}{*}{$\mathrm{P}(\mathrm{mP}-4)$} & DMSO(14) & 101 & 0.17 & - & - & 67.31 & 4.96 & 27.57 \\
\hline & & & & & & $(66.92$ & 5.21 & $\left.27.87 ; \mathrm{C}_{28} \mathrm{H}_{26} \mathrm{~N}_{10}\right)$ \\
\hline \multirow[t]{2}{*}{$\mathrm{P}(\mathrm{mP}-6)$} & DMSO(12) & 101 & 0.20 & - & - & 67.51 & 5.79 & 25.72 \\
\hline & & & & & & $(67.91$ & 5.70 & $\left.26.40 ; \mathrm{C}_{30} \mathrm{H}_{30} \mathrm{~N}_{10}\right)$ \\
\hline \multirow[t]{2}{*}{$\mathrm{P}(\mathrm{mP}-10)$} & $\operatorname{DMSO}(21)$ & 101 & 0.14 & - & - & 69.79 & 6.71 & 23.50 \\
\hline & & & & & & $(69.60$ & 6.53 & $\left.23.87 ; \mathrm{C}_{34} \mathrm{H}_{38} \mathrm{~N}_{10}\right)$ \\
\hline \multirow[t]{2}{*}{$P(E-4)$} & $\operatorname{DMSO}(10) \&$ & 97 & 0.06 & - & - & 63.28 & 5.97 & 30.74 \\
\hline & DMF (8) & & & & & $(63.42$ & 5.77 & $\left.30.82 ; \mathrm{C}_{24} \mathrm{H}_{26} \mathrm{~N}_{10}\right)$ \\
\hline \multirow[t]{2}{*}{$P(E-6)$} & $\operatorname{DMSO}(8) \&$ & 82 & 0.13 & 2.4 & 1.4 & 64.71 & 6.32 & 28.96 \\
\hline & DMA(8) & & & & & $(64.71$ & 6.27 & $\left.29.02 ; \mathrm{C}_{26} \mathrm{H}_{30} \mathrm{~N}_{10}\right)$ \\
\hline \multirow[t]{2}{*}{$P(E-10)$} & DMSO(18) & 102 & 0.17 & 3.4 & 1.6 & 66.42 & 7.65 & 26.51 \\
\hline & & & & & & $(66.89$ & 7.11 & $\left.26.00 ; \mathrm{C}_{30} \mathrm{H}_{38} \mathrm{~N}_{10}\right)$ \\
\hline \multirow[t]{2}{*}{$\mathrm{P}(\mathrm{B}-4)$} & DMSO(8) \& & 99 & 0.12 & 1.6 & 1.2 & 64.55 & 6.00 & 29.04 \\
\hline & DMF(20) & & & & & $(64.71$ & 6.27 & $\left.29.02 ; \mathrm{C}_{26} \mathrm{H}_{30} \mathrm{~N}_{10}\right)$ \\
\hline \multirow[t]{2}{*}{$\mathrm{P}(\mathrm{B}-6)$} & $\operatorname{DMSO}(8) \&$ & 85 & 0.13 & 2.3 & 1.4 & 65.83 & 6.81 & 27.84 \\
\hline & DMA(8) & & & & & $(65.86$ & 6.71 & $\left.27.43 ; \mathrm{C}_{28} \mathrm{H}_{34} \mathrm{~N}_{10}\right)$ \\
\hline \multirow[t]{2}{*}{$\mathrm{P}(\mathrm{B}-10)$} & DMSO(16) & 102 & 0.16 & 3.3 & 1.6 & 67.81 & 7.57 & 24.27 \\
\hline & & & & & & $(67.82$ & 7.47 & $\left.24.71 ; \mathrm{C}_{32} \mathrm{H}_{42} \mathrm{~N}_{10}\right)$ \\
\hline \multirow[t]{2}{*}{$\mathrm{P}(\mathrm{O}-4)$} & $\operatorname{DMSO}(16)$ & 105 & 0.14 & 3.6 & 1.3 & 66.80 & 7.12 & 26.08 \\
\hline & & & & & & $(66.89$ & 7.11 & $\left.26.00 ; \mathrm{C}_{30} \mathrm{H}_{38} \mathrm{~N}_{10}\right)$ \\
\hline \multirow[t]{2}{*}{$\mathrm{P}(\mathrm{O}-6)$} & $\operatorname{DMSO}(16)$ & 102 & 0.15 & 4.9 & 1.5 & 68.08 & 7.32 & 24.60 \\
\hline & & & & & & $(67.82$ & 7.47 & $\left.24.71 ; \mathrm{C}_{32} \mathrm{H}_{42} \mathrm{~N}_{10}\right)$ \\
\hline \multirow[t]{2}{*}{$\mathrm{P}(\mathrm{O}-10)$} & $\operatorname{DMSO}(21)$ & 103 & 0.25 & 13.7 & 1.7 & 69.79 & 8.33 & 21.76 \\
\hline & & & & & & $(69.42$ & 8.09 & $\left.22.49 ; \mathrm{C}_{36} \mathrm{H}_{50} \mathrm{~N}_{10}\right)$ \\
\hline
\end{tabular}

${ }^{a}$ Bisguanamine and $\alpha, \omega$-dibromoalkane were used $5 \mathrm{mmol}$, respectively, and polymerized at room temperature for $22-24 \mathrm{~h}^{\mathrm{b}} c=0.2 \mathrm{~g} \mathrm{dl}^{-1}$ in NMP at $30^{\circ} \mathrm{C}$. ${ }^{\mathrm{c}}$ Determined by GPC in THF using polystyrene as a standard.

Table IV. ${ }^{1} \mathrm{H}$ NMR data of polymers $\mathrm{P}(\mathrm{R}-10)$ in $\mathrm{DMSO}-d_{6}(\delta \mathrm{ppm})$

\begin{tabular}{|c|c|c|c|c|c|}
\hline $\begin{array}{l}\text { Polymer } \\
\text { P(R-10) }\end{array}$ & $\begin{array}{c}\mathrm{NH}_{2} \\
(4 \mathrm{H}, \mathrm{brs})\end{array}$ & $\begin{array}{c}\mathrm{Ph} \\
(10 \mathrm{H}, \mathrm{s})\end{array}$ & $\begin{array}{c}\mathrm{CH}_{2}{ }^{\mathrm{a}} \\
(4 \mathrm{H}, \mathrm{brs})\end{array}$ & $\begin{array}{l}\left(\mathrm{CH}_{2}\right)_{8}{ }^{b} \\
(16 \mathrm{H}, \mathrm{brs})\end{array}$ & $\mathrm{R}$ \\
\hline $\mathrm{P}(\mathrm{pP}-10)$ & 6.98 & 7.28 & 4.00 & 1.15 & $8.29(4 \mathrm{H}, \mathrm{s})$ \\
\hline $\mathrm{P}(\mathrm{mP}-10)$ & 6.91 & 7.30 & 4.02 & 1.14 & $9.19(1 \mathrm{H}, \mathrm{s}), 8.34(2 \mathrm{H}, \mathrm{br} \mathrm{s}), 7.55(1 \mathrm{H}, \mathrm{t})$ \\
\hline$P(E-10)$ & 6.73 & 7.26 & 3.88 & 1.14 & $2.81(4 \mathrm{H}, \mathrm{brs})$ \\
\hline $\mathrm{P}(\mathrm{B}-10)$ & 6.70 & 7.27 & 3.91 & 1.18 & $2.38(4 \mathrm{H}, \mathrm{brs}), 1.67(4 \mathrm{H}, \mathrm{brs})$ \\
\hline $\mathrm{P}(\mathrm{O}-10)$ & 6.73 & 7.27 & 3.87 & 1.18 & $2.36(4 \mathrm{H}, \mathrm{brs}), 1.18(12 \mathrm{H}$, br s $)$ \\
\hline
\end{tabular}


in addition to usual absorption bands of amino-1,3,5-triazine which appeared at 15001600,1420 , and $820 \mathrm{~cm}^{-1}$. The NMR spectra of a series of $\mathrm{P}(\mathrm{R}-10)$ (Table IV) are very similar to those of the corresponding model compounds.

Solubilities of polymers were examined. All polyguanamines are soluble in dipolar aprotic solvents such as $N$-methyl pyrrolidone (NMP), $N, N$-dimethyl acetamide (DMA), and DMSO, and acidic solvent such as formic acid and sulfuric acid, but insoluble in common organic solvents. Polyguanamines without phenylene moiety in the main chain are soluble in dioxane and THF. The molecular weights of the polymers measured by GPC in THF using polystyrene as a standard were $1-5 \times 10^{3}$, except $\mathrm{P}(\mathrm{O}-10)$ with higher molecular weight because the polycondensation proceeded in homogeneous solution.

\section{Thermal Properties}

Glass transition temperatures $\left(T_{\mathrm{g}}\right)$ of polyguanamines were evaluated by means of DSC measurements (Table V). $T_{\mathrm{g}} \mathrm{s}$ of polyguanamines containing phenylene moiety such as $\mathrm{P}(\mathrm{pP}-\mathrm{n})$ and $\mathrm{P}(\mathrm{mP}-\mathrm{n})$ were observed in the range of $154-224^{\circ} \mathrm{C}$ higher than those of $\mathrm{P}(\mathrm{E}-\mathrm{n}), \mathrm{P}(\mathrm{B}-\mathrm{n})$, and $\mathrm{P}(\mathrm{O}-\mathrm{n})$ without phenylene moiety. $T_{\mathrm{g}} \mathrm{s}$ of $\mathrm{P}(\mathrm{R}-\mathrm{n})$ decreased with increasing number of methylene group in the main chain for " $R$ " series as well as for " $n$ " series.

Decomposition temperatures $\left(T_{\mathrm{d}}\right)$ of polymers were determined by TGA measurement.
The results are summarized in Table VI. $T_{\mathrm{d}} \mathrm{s}$ of polyguanamines containing phenylene group were above $450^{\circ} \mathrm{C}$, and those of containing only alkylene group were 400 $450^{\circ} \mathrm{C}$.

\section{Catalytic Activity for Substitution Reaction}

Poly(4-vinylpyridine) is well known as a polymeric ligand. One of authors previously reported that the polymers containing 2pyridylthio group in the main chain ${ }^{10}$ as well

Table V. Glass transition temperatures $\left(T_{\mathrm{g}}\right)$ of polyguanamines, $P(R-n)$

\begin{tabular}{|c|c|c|c|c|c|c|}
\hline \multirow{2}{*}{$n$} & \multicolumn{6}{|c|}{$T_{\mathrm{g}} /{ }^{\circ} \mathrm{C}^{\mathrm{a}}$} \\
\hline & $\mathrm{R}$; & $\mathrm{pP}$ & $\mathrm{mP}$ & $\mathrm{E}$ & B & $\mathrm{O}$ \\
\hline 4 & & 197 & 224 & 142 & 116 & 96 \\
\hline 6 & & 164 & 207 & 128 & 109 & 86 \\
\hline 10 & & 177 & 154 & 107 & 89 & 76 \\
\hline
\end{tabular}

${ }^{a}$ Glass transition temperature was measured by DSC at a heating rate of $20^{\circ} \mathrm{C} \mathrm{min}^{-1}$.

Table VI. Decomposition temperatures $\left(T_{\mathrm{d}}\right)$ of polyguanamines, $\mathrm{P}(\mathrm{R}-\mathrm{n})$

\begin{tabular}{|c|c|c|c|c|c|c|}
\hline \multirow{2}{*}{$n$} & \multicolumn{6}{|c|}{$T_{\mathrm{d}} /{ }^{\circ} \mathrm{C}^{\mathrm{a}}$} \\
\hline & $\mathrm{R}$; & $\mathrm{pP}$ & $\mathrm{mP}$ & $\mathrm{E}$ & B & $\mathrm{O}$ \\
\hline 4 & & 476 & 478 & 401 & 418 & 427 \\
\hline 6 & & 468 & 478 & 446 & 440 & 436 \\
\hline 10 & & 458 & 458 & 441 & 434 & 443 \\
\hline
\end{tabular}

${ }^{a}$ Decomposition temperature was determined by TGA at a heating rate of $10^{\circ} \mathrm{C} \mathrm{min}^{-1}$.

Table VII. Yield of octylthiocyanate of the reaction of 1-bromooctane with potassium thiocyanate under two-phase condition using polyguanamines, $\mathrm{P}(\mathrm{R}-\mathrm{n})$, as a phase-transfer catalyst

\begin{tabular}{lclccc}
\hline Catalyst & Yield $/ \%$ & Catalyst & Yield $/ \%$ & Catalyst & Yield $/ \%$ \\
\hline None & 24 & BTEAC $^{\mathbf{b}}$ & 47 & $\mathbf{2 a}$ & 56 \\
P(pP-4) & 99 & P(pP-6) & 89 & P(pP-10) & 74 \\
P(mP-4) & 95 & P(mP-6) & 65 & P(mP-10) & 77 \\
P(E-4) & 99 & P(E-6) & 96 & P(E-10) & 93 \\
P(B-4) & 99 & P(B-6) & 76 & P(B-10) & 99 \\
P(O-4) & 99 & P(O-6) & 70 & P(O-10) & 99 \\
\hline
\end{tabular}

${ }^{\text {a }}$ Conditions: 1 -bromooctane $=1.65 \mathrm{mmol}$; potassium thiocyanate $=8.0 \mathrm{~mol}^{-1}$ (in water), $5 \mathrm{ml}$; and catalyst $=$ $0.3 \mathrm{mmol}$ at $100^{\circ} \mathrm{C}$ for $30 \mathrm{~h}$ under stirring. ${ }^{\mathrm{b}}$ Benzyltriethylammonium chloride. 
as in the side chain ${ }^{11}$ worked as polymeric phase-transfer catalyst. The catalytic activity of polyguanamines was tested for the reaction of 1-bromooctane in toluene with potassium thiocyanate in water. Polymers were insoluble in toluene, therefore the reaction proceeded under a triphase system. The results are summarized in Table VII. As can be seen from Table VII, the reaction was achieved in the presence of model compound $\mathbf{2 a}$ and polyguanamines. The activity of $\mathbf{2 a}$ was higher than that of benzyltriethylammonium chloride (BTEAC), a typical phase-transfer catalyst. Further, it should be noted that the catalytic activity of polymers is superior to that of model-compound. These observations can be understood by assumption that a potassium cation interacts with several active sites to form a complex, and the resulting anion attacks the substrate. This cooperative coordination of active sites would function effectively in polymers. Since the pendant amino group of guanamine works as an electron-donating one, the basicity of nitrogen atoms in triazine ring is higher than that of pendant amino group. Morimoto $^{12}$ reported that the protonation of 2,4-diamino-1,3,5-triazine and 2,4-diamino-6methyl-1,3,5-triazine occured to nitrogen atom of 3-position in triazine ring because the both neighboring carbons bear amino group. Therefore the active site of guanamine will be nitrogen atom in triazine ring. Furthermore, the activity of a series of polymer containing butylene group $\mathrm{P}(\mathrm{R}-4)$ is a little superior to that of $P(R-6)$ and $P(R-10)$. This may be that two guanamine groups work cooperatively through shorter butylene group. However, the quantitative evaluation of the reactivity of these polyguanamines requires further studies.

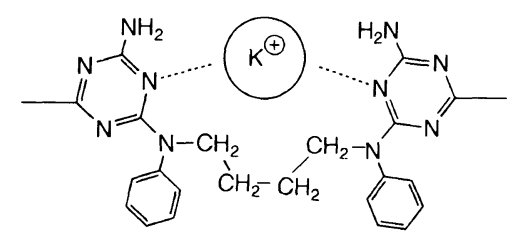

\section{REFERENCES}

1. Y. Yuki, T. Kakurai, and T. Noguchi, Kobunshi Kagaku, 29, 127 (1972).

2. Y. Yuki, K.Sumiyosi, T. Kakurai, and T. Noguchi, Kobunshi Kagaku, 29, 942 (1972).

3. T. Seo, H. Ishiwata, and T. Kakurai, Nippon Kagaku Kaishi, 2419 (1974).

4. H. K. Reimschuessel, A. M. Lovelace, and E. D. Hgaerman, J. Polym. Sci., 40, 136 (1959).

5. H. Kunisada, Y. Yuki, S. Kondo, J. Miyatake, and C. Maeda, Polym. J., 22, 559 (1990).

6. H. Kunisada, Y. Yuki, S. Kondo, K. Adachi, and N. Takahashi, Polymer, 33, 3512 (1992).

7. H. Kunisada, Y. Yuki, S. Kondo, and H. Igarashi, Polymer, 32, 2283 (1991).

8. F. H. S. Curd and F. L. Rose, J. Chem. Soc., 729 (1946).

9. D. Sheehan, A. P. Bentz, and J. C. Petropoulos, J. Appl. Polym. Sci., 6, 47 (1962).

10. S. Kondo, M. Nakanishi, and K. Tsuda, J. Polym. Sci. Polym. Chem. Ed., 23, 581 (1985).

11. S. Kondo, M. Nakanishi, K. Yamane, A. Horibe, and K. Tsuda, J. Appl. Polym. Sci., 32, 4255(1986).

12. G. Morimoto, Nihon Kagaku Zasshi, 87, 785, 790 (1966). 